\title{
Anaemia in Pregnant Women of Sokoto Residents in North Western Nigeria
}

Buhari $\mathbf{H}^{1}$, Imoru $\mathbf{M}^{2^{\star}}$ and Erhabor $\mathrm{O}^{1}$

${ }^{1}$ Haematology Department, Faculty of Medical Laboratory Sciences, Usmanu Danfodio University, Sokoto, Nigeria

${ }^{2}$ Department of Haematology, Aminu Kano Teaching Hospital, Kano, Nigeria

*Corresponding author: Imoru Momodu, Department of Haematology, Aminu Kano Teaching Hospital, Kano, Nigeria, Tel: +234-803-317-4997; E-mail: imorumomodu67@yahoo.com

Received date: Jul 22, 2016, Accepted date: Sep 15, 2016, Publication date: Sep 19, 2016

Copyright: (c) 2016 Buhari $\mathrm{H}$, et al. This is an open-access article distributed under the terms of the Creative Commons Attribution License, which permits unrestricted use, distribution, and reproduction in any medium, provided the original author and source are credited.

\section{Abstract}

Background: In developing countries, anaemia is a cause of serious concern as it contributes significantly to high maternal mortality. The aim of this study was to assess the prevalence of anaemia among pregnant women in Sokoto, Northern Nigeria due to scanty information in this region.

Materials and Methods: The study was conducted on 273 pregnant women at Usmanu Danfodio University Teaching Hospital (UDUTH), Sokoto between June and November, 2015. Socio-demographic characteristics of the pregnant women were collected using structured questionnaire while the red cell parameters of each subject were determined using haematology analyser.

Results: Overall prevalence of anaemia was $39.2 \%$ while the prevalence of anaemia with respect to pregnant women less than 19 years, 20-24 years, 25-29 years, 30-34 years, 35-39 years and $\leq 40$ years were $50.0 \%, 46.8 \%$, $38.9 \%, 37.5 \%, 23.3 \%$, and $100.0 \%$, respectively. Out of all the anaemic pregnant women, $86.0 \%$ had mild anaemia, $14.0 \%$ had moderate anaemia and none had severe anaemia. The means and standard deviations of haemoglobin and haematocrit for the pregnant women were $11.1 \pm 1.27 \mathrm{~g} / \mathrm{dL}$ and $33.5 \pm 3.2 \%$, respectively.

Conclusion: The study has revealed an overall prevalence of anaemia in pregnant women of $39.2 \%$ with the highest prevalence amongst those above 40 years. The high prevalence of pregnant women with mild anaemia may be associated with proper antenatal care at UDUTH and good dietary habit. Early booking and improvement on health and nutritional education are recommended.

Keywords: Anaemia; Pregnant women; Sokoto residents; Nigeria

\section{Introduction}

Anaemia is one of the most commonly encountered medical disorders during pregnancy. In developing countries, it is a cause of serious concern as it contributes significantly to high maternal mortality. According to United Nations declaration 1997, anaemia has been considered to be a major public health problem that needs total elimination and has been estimated that globally, two billion people suffer from anaemia or iron deficiency [1,2].

Relative anaemia is normal physiological phenomenon that occurs in pregnancy due to larger increase in plasma volume (approximately $45.0 \%$ in singleton and $50.0-60.0 \%$ in twin gestation) than in red cell mass, resulting in the well-known physiological anaemia of pregnancy while absolute anaemia involves a true decrease in red cell mass, involving increased red cell destruction as in haemoglobinopathy, malaria, bacterial infection as in urinary tract infection, bleeding or decreased red cell production as in nutritional deficiency or chronic disease $[3,4]$.

According to WHO, haemoglobin level below $11 \mathrm{~g} / \mathrm{dL}$ in pregnant women constitutes anaemia and haemoglobin value below $7 \mathrm{~g} / \mathrm{dL}$ is severe anaemia while Center for Disease Control and Prevention (1990), defined anaemia as less than $11 \mathrm{~g} / \mathrm{dL}$ in the first and third trimesters and less than $10.5 \mathrm{~g} / \mathrm{dL}$ in second trimester [5,6]. However, mild, moderate and severe anaemias were classified based on haemoglobin values of $10.0-10.9 \mathrm{~g} / \mathrm{dL}, 7.0-9.9 \mathrm{~g} / \mathrm{dL}$ and less than 7.0 $\mathrm{g} / \mathrm{dL}$, respectively [7].

In India, National Family Health Survey of 1998-1999 showed that $54 \%$ of women in rural and $46 \%$ of women in urban areas were anaemic [8] but in Nigeria, overall prevalence of anaemia of $54.5-62.6 \%$ has been observed in South-southern region of Nigeria $[9,10]$ while prevalence rates of anaemia of $24.5 \%, 40.4 \%$ and $76.5 \%$ have been reported in Kano, Enugu and Abeokuta, respectively [11-13]. However, 21.3-32.5\% prevalence of anaemia have been documented in Ethiopia and Uganda [14-16].

Varying magnitude of prevalence of anaemia in different parts of Nigeria coupled with scanty information in the Northern Nigeria, necessitated the study on the prevalence of anaemia among pregnant women in Sokoto, North-Western Nigeria. It is our believe that the knowledge of this study will enhance the control or prevention of anaemia in this locality.

\section{Materials and Methods}

\section{Study design}

The study was conducted on pregnant women attending antenatal clinic of Usmanu Danfodio University Teaching Hospital (UDUTH), Sokoto after the ethical clearance from the ethical committee of 
UDUTH and informed consent sought from all the participants. A total of 273 pregnant women using the sample size's formula of Areoye [17], aged 18-42 years, were enrolled in this study between June and November, 2015.

Pregnant women who gave informed consent and resident in Sokoto State of Nigeria were included in this study while the pregnant women with bleeding disorders and/or receiving therapy for anaemia and those ones who refused to give informed consent were excluded from the study.

\section{Sample collection}

Two milliliters of blood was collected from each subject through the antecubital vein, into the EDTA bottle for the determination of haemoglobin, haematocrit and red cell indices using Mythic 22 CT-2008 haematology analyzer. The control reagents were run to check for the accuracy and precision of the haematology analyser.

\section{Data collection}

Data on the socio-demographic characteristics of pregnant were collect using structured questionnaire. According to WHO [7], anaemia in pregnancy was defined as haemoglobin $<11 \mathrm{~g} / \mathrm{dL}$ while mild, moderate and severe anaemias were based on haemoglobin measurements of 10.0-10.9 g/dL, 7.0-9.9 g/dL and less than $7 \mathrm{~g} / \mathrm{dL}$, respectively. These criteria were used in this study.

\section{Data analysis}

Data were analysed using statistical package for social sciences (SPSS package) version 20 (SPSS, Chicago, USA). Values were expressed as mean \pm standard deviation and comparative analysis was done using chi-square test and graphically (Microsoft Excel 2010). Level of significance was set at $\mathrm{p}<0.05$.

\section{Results}

Table 1 shows the red cell parameters of apparently healthy pregnant women. The means and standard deviations of haemoglobin concentration, haematocrit, RBC count, mean cell volume (MCV), mean cell haemoglobin $(\mathrm{MCH})$, mean corpuscular haemoglobin concentration (MCHC) and red cell distribution with (RDW) were $11.1 \pm 1.27 \mathrm{~g} / \mathrm{dL}, 33.5 \pm 3.2 \%, 3.63 \pm 0.43 \times 10 \wedge 12 / \mathrm{L}, 92.9 \pm 8.1 \mathrm{fl}$, $31.0 \pm 3.0 \mathrm{pg}, 33.2 \pm 0.43 \mathrm{~g} / \mathrm{dL}$ and $13.7 \pm 1.2 \%$, respectively.

Prevalence of anaemia among the pregnant women is revealed in Table 2. Out of 273 of the participants in this study, 107 of them were anaemic (39.2\%) using a cut-off level of haemoglobin $<11 \mathrm{~g} / \mathrm{dL}$.

Effect of age on the prevalence of anaemia among the pregnant women is shown in Table 3 . The prevalence of anaemia with respect to age groups less than 19 years, 20-24 years, 25-29 years, 30-34 years, $35-39$ years, and $\geq 40$ years were $50.0 \%, 46.8 \%, 38.9 \%, 37.5 \%, 23.3 \%$, and $100.0 \%$, respectively. The prevalence rates of anaemia with different age groups showed significance $(\mathrm{p}>0.05)$.

Table 4 shows the classification of anaemia amongst anaemic pregnant women. Out of all the anaemic pregnant women, $86.0 \%$ had mild anaemia, $14.0 \%$ had moderate anaemia and none had severe anaemia $(0 \%)$.
Influence of age on haemoglobin values of pregnant women is shown in Figure 1. There was statistically significant difference in haemoglobin level with age $(\mathrm{p}<0.05)$.

\begin{tabular}{|l|l|}
\hline Parameter & Mean \pm SD (n=273) \\
\hline Haemoglobin $(\mathrm{g} / \mathrm{dL})$ & $11.1 \pm 1.27$ \\
\hline Haematocrit $(\%)$ & $33.5 \pm 3.2$ \\
\hline RBC count $\left(\times 10^{\wedge} 12 / \mathrm{L}\right)$ & $3.63 \pm 0.43$ \\
\hline MCV (fl) & $92.9 \pm 8.1$ \\
\hline MCH (pg) & $31.0 \pm 3.0$ \\
\hline MCHC (g/dL) & $33.2 \pm 0.43$ \\
\hline RDW (\%) & $13.7 \pm 1.2$ \\
\hline
\end{tabular}

Table 1: Red cell parameters of healthy pregnant women in Sokoto.

\begin{tabular}{|l|l|l|l|}
\hline & $\begin{array}{l}\text { Anaemic } \\
\text { number }\end{array}$ & $\begin{array}{l}\text { Non- } \\
\text { Anaemic } \\
\text { number }\end{array}$ & $\begin{array}{l}\text { Total } \\
\text { number }\end{array}$ \\
\hline Frequency (number) & 107 & 166 & 273 \\
\hline Percentage (\%) & 39.2 & 60.8 & 100.0 \\
\hline
\end{tabular}

Table 2: Prevalence of anaemia among pregnant women.

\begin{tabular}{|l|l|l|l|l|l|}
\hline $\begin{array}{l}\text { Age } \\
\text { (years) }\end{array}$ & $\begin{array}{l}\text { Anaemic } \\
\text { number (\%) }\end{array}$ & $\begin{array}{l}\text { Non-anaemic } \\
\text { number (\%) }\end{array}$ & $\begin{array}{l}\text { Total } \\
\text { number (\%) }\end{array}$ & $\mathbf{X}^{2}$ & p-value \\
\hline$<19$ & $4(50.0)$ & $4(50.0)$ & $8(2.9)$ & & \\
\hline $20-24$ & $29(46.8)$ & $33(53.2)$ & $62(22.7)$ & & \\
\hline $25-29$ & $42(38.9)$ & $66(61.1)$ & $108(39.6)$ & & \\
\hline $30-34$ & $24(37.5)$ & $40(62.5)$ & $64(23.4)$ & 6.7227 & 0.2421 \\
\hline $35-39$ & $7(23.3)$ & $23(76.7)$ & $30(11.0)$ & & \\
\hline$>40$ & $1(100.0)$ & $0(0)$ & $1(0.4)$ & & \\
\hline
\end{tabular}

Table 3: Effect of age on the prevalence of anemia among pregnant women.

\begin{tabular}{|l|l|l|}
\hline Anaemia classification (\%) & $\begin{array}{l}\text { Frequency } \\
\text { (number) }\end{array}$ & Percentage \\
\hline Mild anaemi & 92 & 86.0 \\
\hline Moderate anaemia & 15 & 14.0 \\
\hline Severe anaemia & 0 & 0 \\
\hline
\end{tabular}

Table 4: Classification of anaemia among the anaemic pregnant women. 


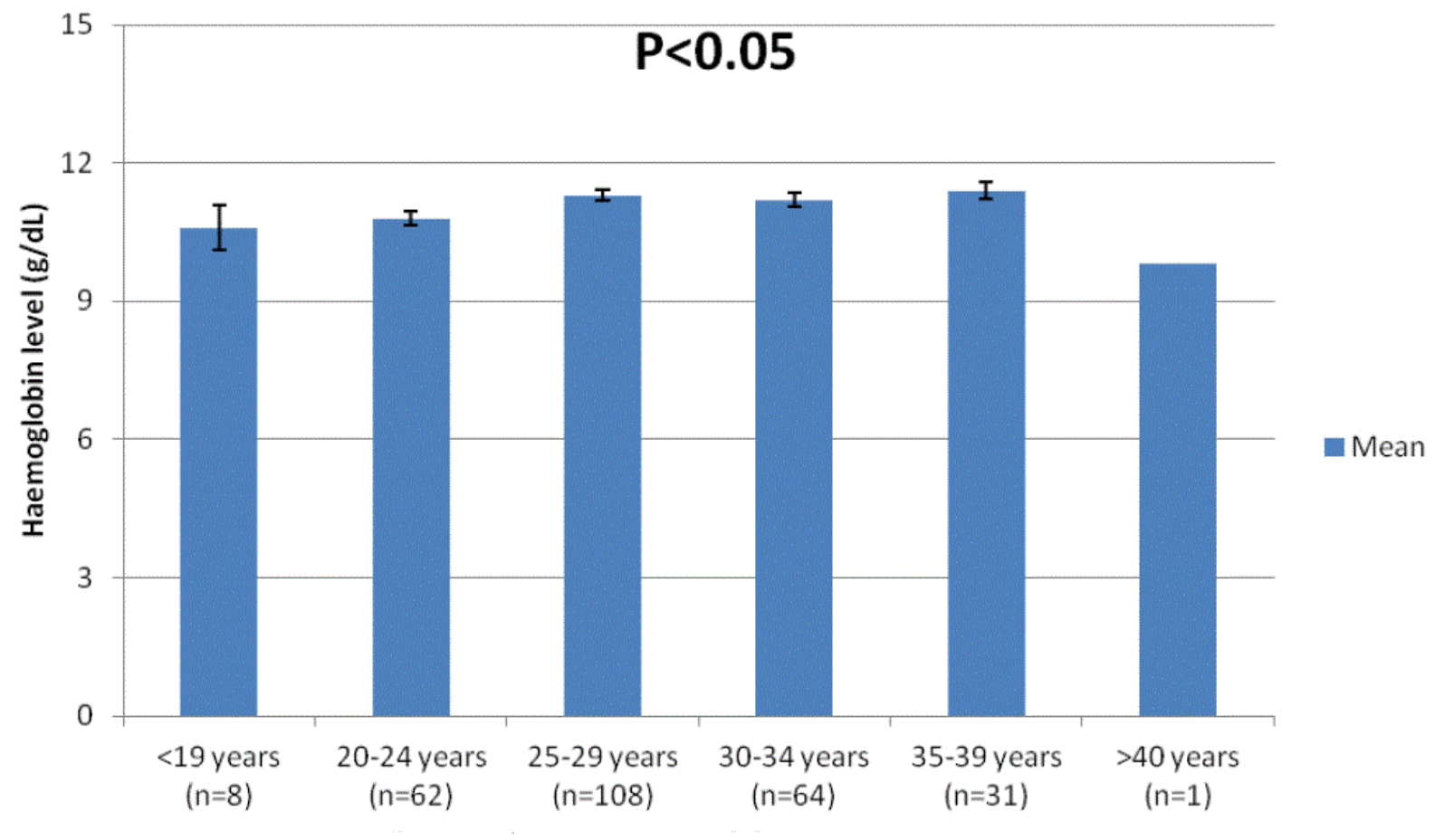

Figure 1: Influence of age on haemoglobin values in pregnant women.

\section{Discussion}

Anaemia is one of the most commonly encountered medical disorders during pregnancy and this is of serious concern in developing countries [2].

The revealed mean values of haemoglobin concentration and haematocrit during pregnancy of $11.1 \pm 1.27 \mathrm{~g} / \mathrm{dL}$ and $33.5 \pm 3.2 \%$, respectively in this study are in line with the previous reports $[9,10,13]$. However, these normal values observed in this study may be associated with increased number of non-anaemic pregnant women (60.8\%) who must have had improved dietary intakes and proper antenatal care at UDUTH. Mean cell volume, MCH and MCHC levels of $92.9 \pm 8.1 \mathrm{fl}$, $31.0 \pm 3.0 \mathrm{pg}$ and $33.2 \pm 0.43 \mathrm{~g} / \mathrm{dL}$, respectively were observed in this research and they are in agreement with the documented normal ranges $[18,19]$.

The overall prevalence of anaemia $(\mathrm{Hb}<11.0 \mathrm{~g} / \mathrm{dL})$ among the pregnant women in this study was $39.2 \%$ and this agrees with the previous findings $[16,20,21]$ but it is contrary with the higher prevalence of $54.5-76.5 \%$ documented by other researchers [9-11]. However, the low prevalence of anaemia in this study may be associated with environmental factors and regular health education provided by the antenatal clinic.

Out of all the anaemic pregnant women, $86.0 \%(92 / 107)$ had mild anaemia, $14.0 \%(15 / 107)$ had moderate anaemia and none had severe anaemia in our study. These findings are consistent with the earlier reports $[10,12,14]$ but the higher prevalence of mild anemia compared to other types of anaemia in this study may be due to adequate knowledge of the factors that could cause anaemia and good dietary habits by the participants.
The differences in the prevalence rates of anaemia in pregnant women with age groups of less than 19 years, 20-24 years, 25-29 years, 30-34 years, 35-39 years, and >40 years, were not statistically significant in this research and these results are similar to the findings of other authors $[15,16]$. However, prevalence of anaemia decreases with increasing age but pregnant women above 40 years had the highest prevalence in this study. This observation may be attributed to reduced sample size for those above 40 years and the believe that anaemia in pregnancy increases with rising parity which leads to repeated drain on iron stores [22]. The high prevalence of anaemia among the pregnant women less than 19 years in this study, agrees with the observation of previous authors $[11,16]$ but disagrees with the other researcher [9]. However, the high prevalence amongst the teenage mothers may be associated with lack of awareness or poor knowledge of antenatal services and probably failure to book early at the ANC.

Haemoglobin level appeared to increase with increasing age but reduced drastically after the age of 40 years in this study and these findings are in contrary with the previous author [13] who reported decreasing PCV value at advancing maternal age. This observation amongst the aging pregnant women in this study may probably be associated with reduced haemodilution, good antenatal services and improved dietary intakes.

In conclusion, the study has revealed an overall prevalence of anemia in pregnant women of $39.2 \%$ with the highest prevalence amongst those above 40 years. The high prevalence of pregnant women with mild anaemia amongst other types of anaemia in this study may possibly be associated with awareness on the causes of anaemia, proper antenatal care and good dietary habit. However, early booking for antenatal care and improvement on health and nutrional education 
among other antenatal services are strongly recommended as these will significantly reduce the relatively high prevalence of anaemia in this locality.

\section{References}

1. UNICEF, Micronutrient Initiative (2004) Vitamin and mineral deficiency: a global progress report.

2. Sharma JB, Shankar M (2010) Anaemia in pregnancy. JIMSA 23: 253-260.

3. Geelgoed D, Agadzi F, Visser L, Ablordeppey E, Asare K, et al. (2006) Severe anaemia in pregnancy in rural Ghana: a case-control study of causes and management. Acta Obstet Gynecol Scand 85: 1165-1171.

4. Bukar M, Audu BM, Sadauki HM, Elnafaty AU, Mariga AG (2009) Prevalence of iron deficiency and magaloblastic anaemia at booking in a secondary Health Facility in North Eastern Nigeria. Nigerian J Med 50: 33-37.

5. World Health Organization (1992-1993) The prevalence of anaemia in pregnancy. WHO Technical reports.

6. Centers for Disease Control (CDC) (1989) CDC criteria for anemia in children and childbearing-aged women. MMWR Morb Mortal Wkly Rep 38: 400-404.

7. WHO (2011) Haemoglobin concentrations for the diagnosis of anaemia and assessment of severity. Vitamin and mineral nutrition information system, World Health Organization.

8. Kennedy E, Meyers L (2005) Dietary reference intakes: development and uses for assessment of micronutrient status of women--a global perspective. Am J Clin Nutr 81: 1194S-1197S.

9. Udukwu GU, Dienye PO (2012) Prevalence and socio-demographic factors associated with anaemia in pregnancy in a primary health centre in Rivers State, Nigeria. Afr J Prm Health Care Fam Med 4: 328.

10. Olatunbosun OA, Abasiattai AM, Bassey EA, James RS, Ibadan G, et al (2014) Prevalence of anaemia among pregnant women at booking in the University of Uyo Teaching Hospital, Uyo Nigeria. Biomed Res Int 2014: 849080 .
11. Idowu OA, Mafiana CF, Dapo S (2005) Anaemia in pregnancy: a survey of pregnant women in Abeokuta, Nigeria. Afr Health Sci 5: 295-299.

12. Dim CC, Onah HE (2007) The prevalence of anemia among pregnant women at booking in Enugu, South Eastern Nigeria. Med Gen Med 9: 11.

13. Gwarzo MY, Ugwa EA (2013) The pattern of anaemia in northern Nigerian pregnant women. J Med Med Sci 4: 319-323.

14. Jufar AH, Zewde T (2014) Prevalence of anaemia among pregnant women attending antenatal care at Tikur Abessa Specialized Hospital, Addis Ababa, Ethiopia. Hematol Thromb Dis 2: 125.

15. Kefiyalew F, Zemene E, Asres Y, Gedefaw L (2014) Anemia among pregnant women in Southeast Ethiopia: prevalence, severity and associated risk factors. BMC Res Notes 7: 771.

16. Ononge S, Campbell O, Mirembe F (2014) Haemoglobin status and predictors of anaemia among pregnant women in Mpigi, Uganda. BMC Res Notes 7: 712.

17. Areoye MO (2004) Research methodology with statistics for health and social sciences. Nathadex Publishers, Ilorin. pp: 115-121.

18. Letsky E (1995) Blood volume, haematimics, anaemia. In: de Swiet M (ed.) Medical Disorders in Obstetric Practice (3rd edn) Oxford: Blackwell Science. pp: $33-60$

19. Sharma JB (1998) Medical Complications in pregnancy. In: Sharma JB (ed.) The Obstetric Protocol (1st edn) Jaypee Brothers Medical Publishers Ltd, Delhi. pp: 78-98.

20. Dairo MD, Lawoyin TO (2004) Socio-demographic determinants of anaemia in pregnancy at primary care level: a study in urban and rural Oyo State, Nigeria. Afr J Med Med Sci 33: 213-217.

21. Niguse O, Mossie A, Gobena T (2013) Magnitude of anaemia and associated risk factors among pregnant women attending antenatal care in Shalla Woreda, West Arzi zone, Oromia region, Ethiopia. Ethiopia J Health Sci 23: 165-173.

22. Adinma JIB, Ikechebelu JI, Onyejimbe UN, Amilo G, Adinma E (2002) Influence of antenatal care on heamatocrit value of pregnant Nigerian Igbo women. Trop J Obstet Gynaecol 19: 68-70. 